\title{
Natural Regeneration and Biological Invasion by Pinus caribaea Morelet in Two Vereda Sites: Woody Vegetation Response
}

\author{
Danúbia Magalhães Soares ${ }^{1}$, André R. Terra Nascimento ${ }^{2 *}$, Lorena Cunha Silva², \\ Gastão Viégas de Pinho Júnior ${ }^{3}$ \\ ${ }^{1}$ Graduate Degree Program in Ecology and Natural Resources Conservation, Universidade Federal de \\ Uberlândia, Uberlândia, Minas Gerais \\ ${ }^{2}$ Instituto de Biologia, Universidade Federal de Uberlândia, Uberlândia, Minas Gerais \\ ${ }^{3}$ Elementary/High Schools in Uberlândia, Uberlândia, Minas Gerais \\ Email: ${ }^{*}$ arnterra@gmail.com
}

Received 27 August 2015; accepted 27 October 2015; published 30 October 2015

Copyright (C) 2015 by authors and Scientific Research Publishing Inc.

This work is licensed under the Creative Commons Attribution International License (CC BY).

http://creativecommons.org/licenses/by/4.0/

(c) (i) Open Access

\begin{abstract}
Veredas are regarded as humid complexes of ecological, water and scenery significance in Cerrado biome related to water table outcrop. Direct alterations in these environments can lead to species diversity reduction and also facilitate biological invasion processes. Thus our study aims to investigate the natural regeneration, the coverage of woody vegetation and the invasive species in two sites in secondary successional stage in the central part of Cerrado biome. Our study was carried out at two sites located at Minas Gerais state, Brazil. We established plots randomly throughout transects laid perpendicularly to the vereda's drain line. We used the line intercept method to analyze the vegetation coverage. We set five $10-\mathrm{m}$ width transects in each of both areas, perpendicular to the vereda's drain line to evaluate the distribution of invasive alien species in the two areas. The richness did not vary between communities $(U=67.50 ; p=0.061)$; on the other hand we found significant difference in density estimates $(U=36.50 ; p=0.002)$. We found significant difference between categories for soil coverage in both sites. Grasses showed the highest coverage when compared to the other categories $(K=45.06 ; p<0.001$ for site 1 and $K=67.47 ; p<0.001$ for site 2). We observed a zonation tendency in site 1 , with a higher native grass coverage at middle and backwards zones $(\mathrm{K}=7.734, \mathrm{p}<0.05)$. We only found Pinus caribaea Morelet individuals in the invasive species survey. We recorded 46 Pinus caribaea individuals at site 1 and 116 Pinus caribaea individuals at site 2 . From the latter group we found 13 individuals within the vereda and 103 in the surrounding vegetation. Both sites have a high natural woody plant regeneration potential although the presence of alien grasses in the veredas' edge and Pinus caribaea all over the humidity gradient highlights the vulnerability of these areas to biological invasion.
\end{abstract}

${ }^{*}$ Corresponding author.

How to cite this paper: Soares, D.M., Nascimento, A.R.T., Silva, L.C. and de Pinho Júnior, G.V. (2015) Natural Regeneration and Biological Invasion by Pinus caribaea Morelet in Two Vereda Sites: Woody Vegetation Response. American Journal of Plant Sciences, 6, 2708-2717. http://dx.doi.org/10.4236/ajps.2015.617272 


\section{Keywords}

\section{Woody Species, Ecological Patterns, Invasive Potential, Humid Areas}

\section{Introduction}

Veredas are regarded as humid complexes of ecological, water and scenery significance in Cerrado biome (Figure 1). A vereda is in fact a multiform area showing niches and habitats heterogeneity important to terrestrial and water fauna, plus contributing to the watercourses perenniality [1] [2]. This physiognomy only occurs when there is a water table outcrop surrounded by Mauritia flexuosa L.f. (buriti), palm trees [3]. Nonetheless, since the tree-shrub layer is prevailing, this palm tree species occurrence is questionable when it comes to identify this sort of environment, so there might be areas bearing similar structure and plant composition in which this species does not occur [4].

Distinct flood levels and edaphic characteristics can generate distinct plant species gradients which vary as much as their coverage and soil conditions tolerance [1] [5]. Thus veredas can show three distinct floristic areas: edge, middle and backwards [1]. Although reproductive events of many species present in these environments rely on environmental disturbances such as fire and light condition variations [6], peculiar environmental conditions give veredas a low resilience, thus human activities can lead to severe disturbances in these environments. The soil compaction, water table lowering and biological invasion are challenges that must be overcome in order to maintain and preserve these areas [7].

According to the Technical Report on Cerrado Biome Deforestation released in 2009, Minas Gerais state held in 2008 , nearly $43.2 \%$ of Cerrado remaining areas. The other areas had been removed to make way to any kind of human activity [8]. Even if legally protected by current Brazilian Forest Code, anthropogenic alterations in veredas still occur in despite of their vast distribution. In Triângulo Mineiro region (Minas Gerais state), many of these areas are directly used as natural pastures or drained for subsistence and intensive agriculture [9].

It is generally known that plant community regeneration patterns are determined by a combination of biotic and abiotic factors such as climate conditions, light characteristics, populations' structure and dynamics, interactions with pathogen parasites and the reproductive strategies of the species that compound this community [10]. Nonetheless, the plant species richness might be affected by anthropogenic alterations in the environment. Habitat fragmentation, pasture and edge effects can show a negative relation to diversity in plant communities [11].

Although they are not directly affected, the veredas are highly sensible to environmental disturbances in their surroundings [5]. The edge areas can show significant changes in their floristic composition, according to the characteristics and disturbance levels of the surrounding areas [12]. Moreover, direct alterations in these environments can lead to species diversity reduction and also facilitate biological invasion processes [7].

The biological invasion in veredas by alien species such as the grass Melinis minutiflora P. beauv. as well as by native ones like the shrub species Trembleia parviflora (D. Don) Cogn., might be related to humidity reduction in veredas soils as a result of anthropogenic actions [13]. The latter mentioned species is able to form high density areas with reduced diversity rates known as "trembleiais areas" [14]. Besides, human activities that cause water table lowering can increase the invasive process by leading this species distribution farther into the vereda area (Figure 1(c)) [7].

Disturbed ecosystems can be dominated by native and alien grass species highly productive, which makes the floristic composition in these environments less diverse [15]. Similarly, invasive species belonging to Pinus spp. genus change the natural conditions by unbalancing the producer-consumer relationship forming a community dominated by few species. They also form a thick layer of litter which hampers the native species regeneration [16]. These invasive species can disperse through long distances away the plantation area carrying with them compatible invasive ectomycorrhiza fungi [17]. There is contamination by these species in Brazil (Figure 1(b)), where Pinus spp. plantations are conspicuous [18]. The contamination by these species occurs in open areas such as natural fields, cerrado sensu stricto, sand banks and secondary forests [19].

Once started the biological invasion process its effects on plant community are varied and in some cases difficult to detect because they are idiosyncratic, subtle, and indirect and its likely significant effects might only can be detectable in a long term [20] [21]. Nonetheless, many negative effects of invasive plants had already 

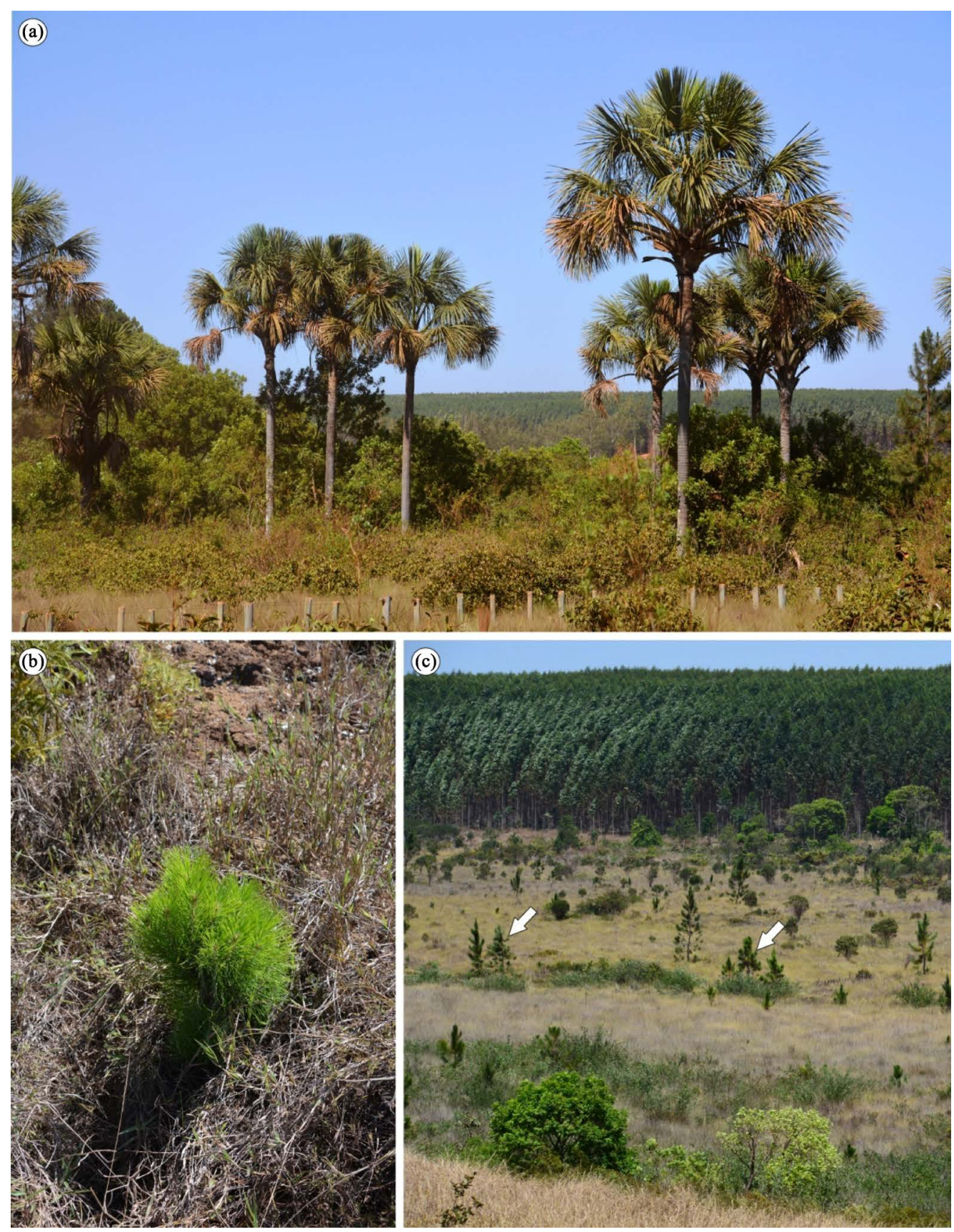

Figure 1. General view of woody community in vereda (a), biological invasion by Pinus caribaea, underscoring an individual from regeneration (b) and individuals growing in a higher density in the drier and without woody vegetation areas (white arrows in (c)). Photos: Nascimento, A.R.T.

been recorded such as: changes in organic matter deposition in soil [22], changes in fire frequency and/or fire occurrence [23], reduction of diversity rates and basal area of native regenerating species in alien species understory [24], fitness reduction in native species by direct competition [25] or apparent competition [26]. In despite of being scarcely understood, the co-occurrence of distinct invasive species also sets a challenge to the understanding of biological conservation efforts [27].

More than isolating disturbed areas, a successful regeneration process requires in some cases strategies to control invasive species and manage native species in late successional process. The correct intervention though relies on ecological knowledge [28] and monitoring the restoration process in field [28] [29]. In this context stu- 
dies on regeneration patterns and alien and native species distribution in veredas can provide some important data on water resources and land use in these ecosystems as well as act as guideline for preservation and management [13]. Thus our study aims to investigate the natural regeneration, the coverage of woody vegetation and the potentially invasive species in two veredas sites in secondary successional stage in the core area of Cerrado biome.

\section{Materials and Methods}

\subsection{Study Area}

Our study was carried out at two vereda sites located at "Nova Monte Carmelo" farm (Figure 1), situated in Minas Gerais state, Brazil. The distance between the studied sites is nearly $12 \mathrm{~km}$. Although the two sites are located at distinct municipalities_site 1 in Estrela do Sul and site 2 in Indianópolis, both fragments are subject to the same anthropogenic pressures as a result of commercial forest plantation at Nova Monte Carmelo farm. Still, the distinct environmental features between both sites can affect the biological invasion process as well as the natural regeneration, since site 1 does not show any vegetation adjacent to vereda, wich makes it more vulnerable to disturbances.

The farm has huge Pinus spp. and Eucalyptus spp. plantations for commercial purposes. The farm is 58,000-hectare large in which 12,000 ha. are legal reserve areas in distinct regeneration stages, characterized by abandoned pastures and cerrado sensu stricto, semideciduous seasonal forest and veredas fragments. According to the Management Plan of Nova Monte Carmelo farm, the set aside areas for restoration are in natural regeneration process [30]. Nevertheless, the vereda areas in this farm show signs of degradation such as the high density presence of invasive species Trembleia parviflora and Pinus caribaea. The weather in this region is characterized as Aw, providing hot and rainy summers and dry and cold winters with a $1450 \mathrm{~mm}$ average precipitation and annual average temperature between $20^{\circ} \mathrm{C}$ and $22^{\circ} \mathrm{C}$ [31].

\subsection{Data Gathering}

We established two distinct size classes to evaluate the natural regeneration process in the two vereda sites: $2 \times$ 2-meter plots (Class I) and $10 \times 10$-meter plots (Class II). We also established fifteen $4 \mathrm{~m}^{2}$ plots (Class I) and fifteen $100 \mathrm{~m}^{2}$ plots (Class II) at each site [32] in the following environments: edge (5 plots), middle (5 plots), and backwards (5 plots). We set these plots randomly throughout transects laid perpendicularly to the vereda's drain line. We identified the environments as edge, middle and backwards according to [1].

We sampled all the regenerating individuals between $15 \mathrm{~cm}$ and $1 \mathrm{~m}$ high in the smaller plots $\left(4 \mathrm{~m}^{2}\right)$ and the woody individuals with $1 \mathrm{~m}$ high and up to $5 \mathrm{~cm}$ D.B.H (Diameter at Breast Height, measured $1.3 \mathrm{~m}$ above the ground) in the larger plots $\left(100 \mathrm{~m}^{2}\right)$. This inclusion criterion for woody vegetation (D.B.H $\geq 5 \mathrm{~cm}$ ) characterizes adult vegetation [33], thus separates the tree layer from the rest of the vegetation.

We identified the sampled woody individuals in situ according to morphological and dendrologic features. When we could not identify these sampled individuals in field we gathered the botanical material and compared it to specialized bibliography and to the botanical material stored at Herbarium Uberlandensis (HUFU). We identified all the collected material according to APG III [34]. We sent the sampled material we could not identify or bearing a doubtful identification to experts.

We used the line intercept method [35] to analyze the vegetation coverage. We sampled fifteen 10-m length lines (five in each environment), the measures were taken directly on the vegetation 1-m above the ground [36]. We set the lines in the $100 \mathrm{~m}^{2}$ plots parallel to the transects and 2-m away from the edge of the plot.

To analyze the coverage distribution in the distincts plant groups we grouped the data into the following categories: alien grasses, native grasses, herbaceous, woody, lianas, ferns and bare soil.

We also evaluated the distribution of potentially invasive alien species in the two sites. For this purpose we set five 10-m width transects in each of both sites, perpendicular to the vereda's drain line, 100-m away from each other starting at the external edge of vegetation adjacent to vereda up to the watercourse (vereda's backwards environment). We measured the Diameter at Breast Height (D.B.H) for each individual found in the transect area higher than 2.5-m. We measured the Diameter at Soil Height (D.S.H) for those between 1-m and 2.5-m high. We also recorded the height estimate, physiognomy and occurrence zone (edge, middle or backwards) for those found inland the vereda sites. 


\subsection{Data Analysis}

We tested the density, richness, coverage and dendrometric parameters (height and D.B.H) of Pinus caribaea (invasive species) for normality using graphic analysis and Kolmogorov-Smirnov test $(\mathrm{p} \leq 0.05)$. We performed this same procedure to test species richness and density data for native species which we represented by using average and standard deviation. Since the coverage data (total and categorized) did not fir normal distribution, we used Kruskal Wallis non parametrical test. We compared the D.B.H and height averages for Pinus caribaea (invasive species) between the two vereda sites using the t-test. We performed ANOVA to compare the averages for trunk diameter and height between the occurrence zones and vegetation types. We performed all the procedures and statistical tests in Systat 10.2 software (Systat Software, Inc, Richmond, Calif).

We investigated the environmental heterogeneity (edge, middle and backwards) inside and amongst the sites by performing a hierarchical cluster analysis according to ward method with the euclidean distance as a clustering coefficient based on the dissimilarity amongst the plots [37]. We created the dendrogram based on Euclidean distance using a presence/absence binary data matrix for the species found in the plots. We used the R software [38] to perform this procedure.

\section{Results and Discussion}

Based on richness and density estimates the woody layer regeneration is significant (Figure 2). The richness did not vary between communities ( $\mathrm{U}=67.50$; $\mathrm{p}=0.061$ ), even though it ranged from 1 to 23 species present in the plots. On the other hand, we found significant difference in the number of individuals per plot estimates $(\mathrm{U}=$ 36.50; $\mathrm{p}=0.002$ ) showing a wider variation between areas (1 to 77 individuals). Oppositely to cerrado sensu stricto where the tree-shrub layer is diverse and species rich [39] in vereda vegetation, this layer shows a low diversity, holding a smaller array of woody species which can tolerate the flood conditions and the hydromorphic soils, both characteristical features of these environments.

The cluster analysis identified two distinct groups: one consists basically of the plots located at site 1 and the other one mainly of plots situated at site 2 (Figure 3). Therefore we could notice the sites hold distinct floristic compositions even showing similar ecological zonation features. The low similarity between the two sites might be related to distinct disturbance levels and soil humidity conditions, since variations in soil humidity can result in differences in plant community composition either between zones in a vereda area or between veredas areas [5]. Although the formation of distinct floristic zones between edge, middle and backwards plots is not clear we observed a lower similarity between edge and backwards plots when compared to all the other categoriescomparison made amongst distinct categories and the same categories.

We did not find any liana species amongst the coverage categories at site 2. In general, the soil coverage did not differ significantly between the two veredas areas except for woody plants category $(U=45 ; p<0.05$ ). The site 2 holds the more significant difference in this category (Figure 4). We found significant difference between categories for soil coverage in both sites. Grasses showed the highest coverage when compared to the other categories ( $K=45.06$; $p<0.001$ for site 1 and $K=67.47$; $p<0.001$ for site 2$)$.

When it comes to zonation we did not find any significant difference in coverage amongst zones (edge, middle and backwards) in the categories for site 2. Conversely, Santos and Munhoz [14] identified three distinct floristic groups throughout a humidity gradient in a vereda area at Distrito Federal (DF, Midwest Brazil). The absence of zonation in site 2 might indicates non significant environmental variations in this area, probably related to a flat local topography.

Nonetheless, we observed a zonation tendency in site 1, with a higher native grass coverage at middle and backwards zones $(K=7.734$; $\mathrm{p}<0.05)$. Floristic surveys in vereda vegetation also identify a higher grass diversity at these zones [14], which might indicates adaptive advantages of this plant group to humid areas.

We only observed alien grasses at edge zone in both sites, with an average coverage of $7.60 \%( \pm 21.35)$ for site $1 \%$ and $0.39 \%( \pm 1.52)$ for site 2 ; this observed coverage is lower when compared to native grass coverage. This species group is usually conspicuous in edge areas, where there is a higher light intensity and wind speed, being this latter responsible for dispersing anemochoric seeds such as Pinus caribaea ones. Moreover, the water table lowering (Figure 1(c)) can facilitate the colonization of the edge of the veredas by species that could not tolerate the humidity conditions usually found at these environments [7]. Although the average coverage by alien grasses is relatively low, environmental and ecological factors might be maintaining these populations at unstable levels thus any change at the environmental conditions could trigger unpredictable invasive processes 


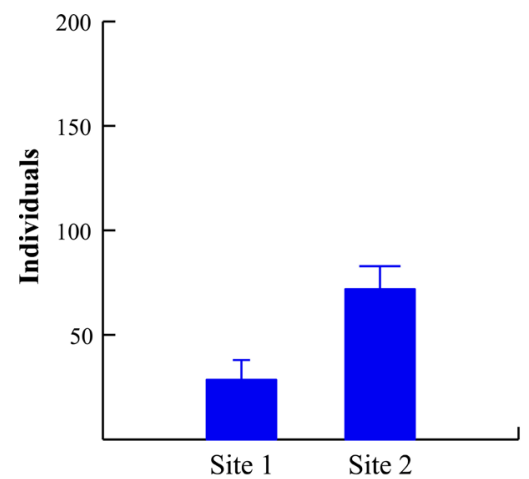

(a)

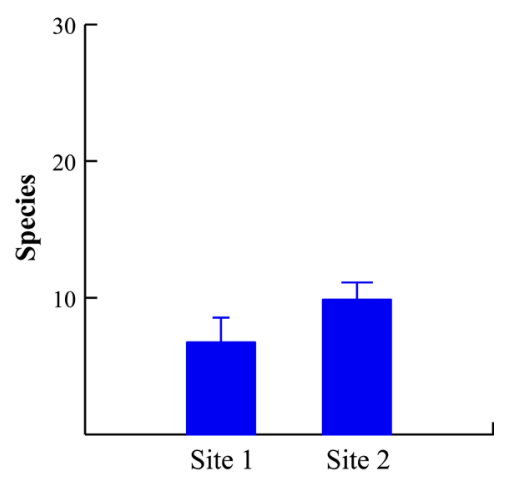

(b)

Figure 2. Density estimates (a) and woody species richness (b) per $100 \mathrm{~m}^{2}$ plot at two veredas in Cerrado biome. Each column represents the average and the bar represents the standard deviation of the estimates ( $\mathrm{N}=15$ samples per area).

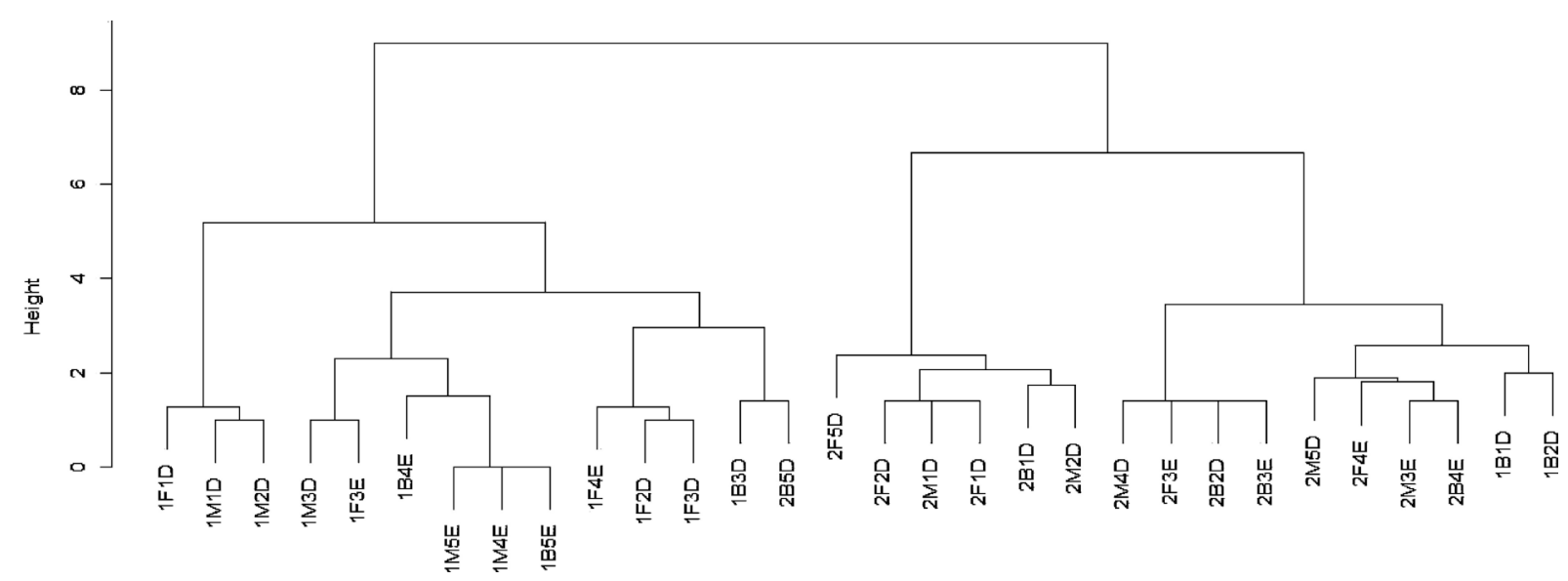

Figure 3. Dendrogram for hierarchical cluster analysis for the two sites using ward's method and the euclidean distance as clustering coefficient. Numbers represent the sites (site 1 and site 2), and letters the zones (E: edge; M: middle; B: backwards).

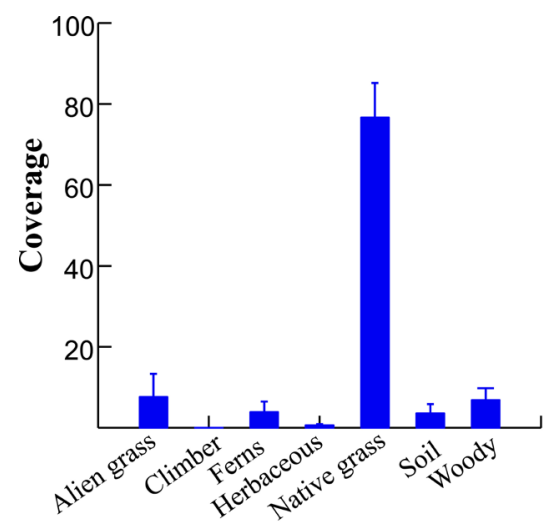

(a)

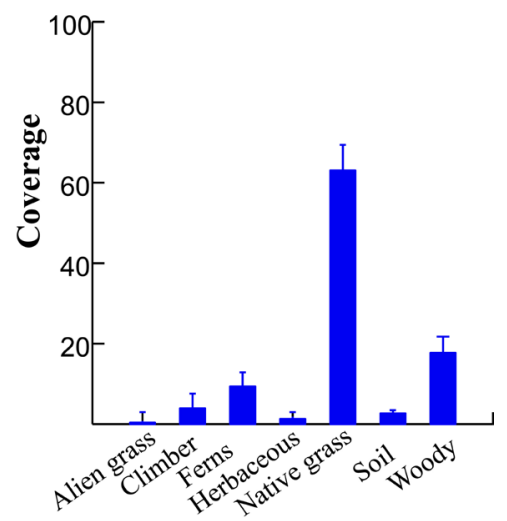

(b)

Figure 4. Total soil coverage (\%) in distinct categories in two veredas sites: site 1 (a) and site 2 (b) Nova Monte Carmelo farm, Estrela do Sul-MG.

[23] [40] therefore the maintenance of this ecosystem takes monitoring and invasive species management methods.

We only found Pinus caribaea individuals in the invasive species survey. We recorded 46 Pinus caribaea individuals at site 1 and 116 Pinus caribaea individuals at site 2. From the latter group we found 13 individuals 
inland the vereda and 103 in the surrounding vegetation.

The Pinus caribaea individuals showed the highest height (Figure 5(a)) at site $2(t=-5.873$; $p<0.01$ ) and the highest diameter (Figure $5(\mathrm{~b})$ ) at site $1(\mathrm{t}=2.538$; $\mathrm{p}=0.012$ ). Since the management at site 1 was done using clearcutting these differences might be related to individual's regrowth at this site.

We did not find any significant variation for diameter in Pinus caribaea individuals at site 1 amongst edge, middle and backwards zone although we found the highest individuals at the edge of the vereda. We found significant differences for both height and diameter amongst zones in vereda 2 at site 2 (Table 1), with the highest individuals found inland (middle and backwards).

We tested the biometrical differences for Pinus caribaea individuals at distinct Cerrado physiognomies at site 2 because we only observed adjacent vegetation to vereda at this area. We recorded the invasive species at the 5 analyzed transects allocated at cerrado sensu stricto, semideciduous seasonal forest (SSF) and bordering Cerrado and SSF and Cerrado and vereda. We did not find any significant difference in height $(F=0.480 ; p=0.697)$ and diameter $(F=1.491 ; p=0.221)$ amongst the distinct physiognomies. This result might indicate that this invasive species population is able to establish at distinct types of vegetation with distinct environmental features.

The Pinus caribaea populations at the two veredas areas studied showed individuals at distinct growing stages, from youngsters to reproductive adult ones, which might play an important role in these ecosystems reinfestation and in the maintenance of these invasive species populations, with the possibility of seed rain and consequently the continuous recruitment of new individuals [41]. The distribution of Pinus caribaea individuals at distinct growing stages might be related to the disturbance and the water table level, which can result in distinct plant communities composition, either in veredas zones or between them [5], with places where these individuals establishment might be restrict or absent. Moreover, the environment disturbance levels can be vital to explain the observed variation [42], since the studied areas and the zones within each vereda are subject to distinct

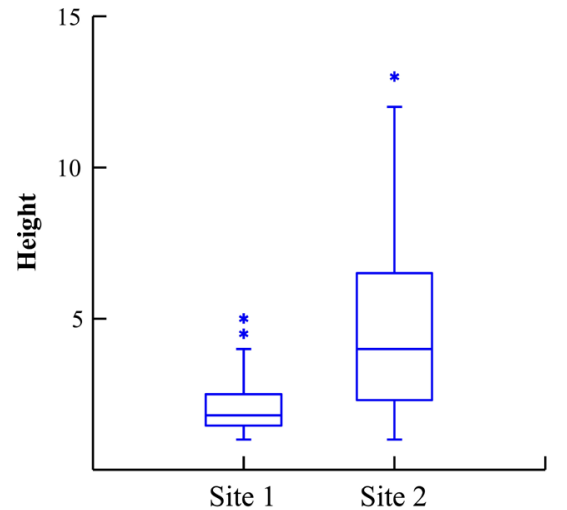

(a)

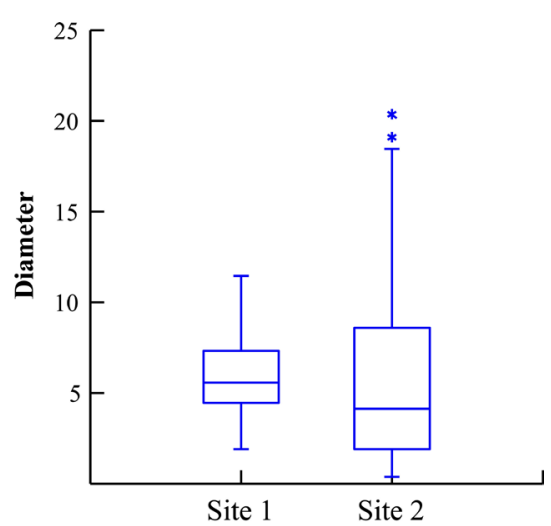

(b)

Figure 5. Diameter measured—centimeters, (a) and height-meters of Pinus caribaea individuals in both sampling sites at Nova Monte Carmelo farm, Estrela do Sul-MG. The boxes represent $50 \%$ of the data, being the central horizontal lines the medians, the superior line represents o 75th percentile and the inferior the 25th percentile. The vertical lines represent the data width, and the asterisks the outliers.

Table 1. Results of ANOVA for height and diameter (on a logarithmic scale) for Pinus caribaea individuals found at edge, middle and backwards veredas at two sites.

\begin{tabular}{|c|c|c|c|c|c|c|c|}
\hline & & Source & Sum-of-squares & $\mathrm{df}$ & Mean-square & F-ratio & $\mathrm{p}$ \\
\hline \multirow{4}{*}{ Site 1} & \multirow{2}{*}{ Diameter } & Zone & 0.085 & 2 & 0.042 & 1.508 & 0.234 \\
\hline & & Error & 1.066 & 38 & 0.028 & & \\
\hline & \multirow{2}{*}{ Height } & Zone & 0.297 & 2 & 0.149 & 4.623 & 0.016 \\
\hline & & Error & 1.222 & 38 & 0.032 & & \\
\hline \multirow{4}{*}{ Site 2} & \multirow{2}{*}{ Diameter } & Zone & 1.323 & 2 & 0.662 & 10.330 & 0.004 \\
\hline & & Error & 0.640 & 10 & 0.064 & & \\
\hline & \multirow{2}{*}{ Height } & Zone & 0.650 & 2 & 0.325 & 15.456 & 0.001 \\
\hline & & Error & 0.210 & 10 & 0.21 & & \\
\hline
\end{tabular}


levels of anthropogenic disturbance, with the presence or not of native vegetation in the surroundings, proximity to cultivated and fragment areas thus these anthropogenic impacts play an important role in the invasive process [23].

\section{Conclusions and Forestry Guidelines}

Both sites show a significant natural regeneration potential represented by density and coverage values in spite of the dominance of some species at certain patches, which normally occurs at vereda vegetation. The presence of alien grasses in the veredas' edge even in low densities highlights the vulnerability of these areas to disturbances in the surroundings indicating the necessity of maintaining surrounding vegetation to act as a buffer zone. The invasion of Pinus caribaea plus the aforementioned features were recorded as an indicative of disturbance, with individuals at distinct growing levels that reached the area through anemochoric dispersion. A forestry guideline to manage this invasive species at this matrix with a higher alien and native grasses biomass would be the clearcutting followed by poisoning the remaining trunks and roots with herbicid, which besides being an usual forestry procedure can also diminish the reifestation. Girdling the remaining individuals might be necessary. These proceedings have to be done before the seeds production in order to avoid their dispersion to the open areas with a lower woody biomass.

\section{Acknowledgements}

We would like to thank Duratex for funding the project of which this study is part. We are also thankful to the graduate Program in Ecology and Natural Resources Conservation and CAPES for the graduate scholarship provided. We are also thankful to the professors Rosana Romero (Melastomataceae), Glein M. Araújo (distinct botany families) and Jimi N. Nakajima (Asteraceae) for helping identify the collected botany material. We would like to thank Cláudio Henrique Eurípedes de Oliveira for his assistance in field.

\section{References}

[1] Araújo, G.M., Barbosa, A.A.A., Arantes, A.A. and Amaral, A. (2002) Composição florística de veredas no município de Uberlândia, MG. Revista Brasileira de Botânica, 25, 475-493. http://dx.doi.org/10.1590/S0100-84042002012000012

[2] Brandão, M., Carvalho, P.G. and Baruqui, F.M. (1991) Veredas: Uma abordagem integrada. Daphne, 1, 9-12.

[3] Ribeiro, J.F. and Walter, B.M.T. (2008) As principais fitofisionomias do Bioma Cerrado. In: Sano, S.M., Almeida, S.P. and Ribeiro, J.F., Eds., Cerrado Ecologia e Flora, Planaltina, 152-212.

[4] Moreira, S.N., Eisenlohr, P.V., Pott, A., Pott, V.J. and Oliveira-Filho, A.T. (2015) Similar Vegetation Structure in Protected and Non-Protected Wetlands in Central Brazil: Conservation Significance. Environmental Conservation, 1, 1-7. http://dx.doi.org/10.1017/S0376892915000107

[5] Oliveira, G.C., Araujo, G.M. and Barbosa, A.A.A. (2009) Florística e zonação de espécies vegetais em veredas no Triângulo Mineiro, Brasil. Rodriguésia, 60, 1077-1085.

[6] Araújo, G.M., Amaral, F.A., Bruna, E.M. and Vasconcelos, H.L. (2013) Fire Drives the Reproductive Responses of Herbaceous Plants in a Neotropical Swamp. Plant Ecology, 214, 1479-1484. http://dx.doi.org/10.1007/s11258-013-0268-9

[7] Meirelles, M.L., Guimarães, A.J.M., Oliveira, R.C., Araújo, G.M. and Ribeiro, J.F. (2004) Impactos sobre o estratoherbáceo de areas úmidas do Cerrado. In: Aguiar, L.M.S. and Camargo, A.J.A., Eds., Cerrado: Ecologia e Caracterização, Planaltina, 41-69.

[8] Ministério do Meio Ambiente (2009) Florestas do Brasil em resumo. Serviço Florestal Brasileiro, Brasília.

[9] Ramos, H.M.V.V., Curi, N., Motta, P.E.F., Vitorino, A.C.T., Ferreira, M.M. and Silva, M.L.N. (2006) Veredas do Triângulo Mineiro: Solos, água e uso. Ciência e Agrotecnologia, 30, 283-293. http://dx.doi.org/10.1590/S1413-70542006000200014

[10] Marimon, B.S., Felfili, J.M., Fagg, C.W., Marimon-Junior, B.H., Umetsu, R.K., Oliveira-Santos, C., Morandi, P.S., Lima, H.S. and Nascimento, A.R.T. (2012) Monodominance in a Forest of Brosimum rubescens Taub. (Moraceae): Structure and Dynamics of Natural Regeneration. Acta Oecologica, 43, 134-139. http://dx.doi.org/10.1016/j.actao.2012.07.001

[11] Cagnolo, L., Cabido, M. and Valladares, G. (2006) Plant Species Richness in the Chaco Serrano Woodland from Central Argentina: Ecological Traits and Habitat Fragmentation Effects. Biological Conservation, 132, 510-519. 
http://dx.doi.org/10.1016/j.biocon.2006.05.012

[12] Resende, I.L.M., Chaves, L.J. and Rizzo, J.A. (2013) Floristic and Phytosociological Analysis of Palm Swamps in the Central Part of the Brazilian Savanna. Acta Botanica Brasilica, 27, 205-225. http://dx.doi.org/10.1590/S0102-33062013000100020

[13] Felfili, M.J., Silva-Junior, M.C.S., Mendonça, R.C., Fagg, C.W., Filgueiras, T.S. and Mecenas, V.V. (2008) Fitofisionomias e flora. In: Fonseca, O.F., Ed., Águas Emendadas, Secretaria de Desenvolvimento Urbano e Meio Ambiente, Brasília, 152-162.

[14] Santos, F.F.M. and Munhoz, C.B.R. (2012) Diversidade de espécies herbáceo-arbustivas e zonação florística em uma vereda no Distrito Federal. Heringeriana, 6, 21-27.

[15] Veldman, J.W. and Putz, F.E. (2011) Grass-Dominated Vegetation, Not Species-Diverse Natural Savanna, Replaces Degraded Tropical Forests on the Southern Edge of the Amazon Basin. Biological Conservation, 144, 1419-1429. http://dx.doi.org/10.1016/j.biocon.2011.01.011

[16] Brown, J.S. and Venable, D.L. (1986) Evolutionary Ecology of Seed-Bank Annuals in Temporally Varying Environments. The American Naturalist, 127, 131-147. http://dx.doi.org/10.1086/284465

[17] Hayward, J., Horton, T.R., Pauchard, A. and Nuñez, M.A. (2015) A Single Ectomycorrhizal Fungal Species Can Enable a Pinus Invasion. Ecology, 96, 1438-1444. http://dx.doi.org/10.1890/14-1100.1

[18] Coelho, V.C.M. (2010) Avaliação do manejo da produção econômica de madeira de Pinus taeda L. com características qualitativas superiores. Unpublished Master’s Thesis, Universida de Federal do Paraná, Curitiba.

[19] Espíndola, M.B., Bechara, F.C., Bazzo, M.S. and Reis, A. (2005) Recuperação ambiental e contaminação biológica: Aspectos ecológicos e legais. Biotemas, 18, 27-38.

[20] Simberloff, D. (2010) Invasions of Plant Communities-More of the Same, Something Very Different, or Both? The American Midland Naturalist, 163, 220-233. http://dx.doi.org/10.1674/0003-0031-163.1.220

[21] Simberloff, D. (2011) How Common Are Invasion-Induced Ecosystem Impacts? Biological Invasions, 13, $1255-1268$. http://dx.doi.org/10.1007/s10530-011-9956-3

[22] Witkowski, E.T.F. (1991) Effects of Invasive Alien Acacias on Nutrient Cycling in the Coastal Lowlands of the Cape Fynbos. Journal of Applied Ecology, 28, 1-15. http://dx.doi.org/10.2307/2404109

[23] Rossi, R.D., Figueira, J.E.C. and Martins, C.R.M. (2010) Capim-gordura, invasão biológica, conservação do cerrado e regime de fogo, Minas Gerais, Brasil. MG Biota, 3, 4-27.

[24] Abreu, R.C.R., de Miranda Santos, F.F. and Durigan, G. (2014) Changes in Plant Community of Seasonally SemiDeciduous Forest after Invasion by Schizolobium parahyba at Southeastern Brazil. Acta Oecologica, 54, 57-64. http://dx.doi.org/10.1016/j.actao.2013.03.013

[25] Vila, M. and Weiner, J. (2004) Are Invasive Plant Species Better Competitors than Native Plant Species? Evidence from Pair-Wise Experiments. Oikos, 105, 229-238. http://dx.doi.org/10.1111/j.0030-1299.2004.12682.x

[26] Dangremond, E.M., Pardini, E.A. and Knight, T.M. (2010) Apparent Competition with an Invasive Plant Hastens the Extinction of an Endangered Lupine. Ecology, 91, 2261-2271. http://dx.doi.org/10.1890/09-0418.1PMid:20836448

[27] Kuebbing, S.E., Nuñez, M.A. and Simberloff, D. (2013) Current Mismatch between Research and Conservation Efforts: The Need to Study Co-Occurring Invasive Plant Species. Biological Conservation, 160, 121-129. http://dx.doi.org/10.1016/j.biocon.2013.01.009

[28] Shono, K., Davies, S.J. and Kheng, C.Y. (2006) Regeneration of Native Plant Species in Restored Forests on Degraded Lands in Singapore. Forest Ecology and Management, 237, 574-582. http://dx.doi.org/10.1016/j.foreco.2006.10.003

[29] Ficko, S., Smith, B. and Zeeb, B. (2015) Assisted Revegetation Following Contaminated Site Remediation in the Arctic: Four-Year Case Study of a Former Radar Site. American Journal of Plant Sciences, 6, 1301-1312. http://dx.doi.org/10.4236/ajps.2015.68130

[30] Duratex (2012) Plano de manejo florestal: Versão pública. http://www.duratex.com.br/pt/Download/Plano de Manejo Florestal Versao Publica 2012.pdf

[31] Alvares, C.A., Stape, J.L., Sentelhas, P.C., Moraes-Gonçalves, J.L. and Sparevek, G. (2013) Köppen’s Climate Classification Map for Brazil. Meteorologische Zeitschrift, 22, 711-728. http://dx.doi.org/10.1127/0941-2948/2013/0507

[32] Pinho Jr., G.V., Nascimento, A.R.T., Valverde, B.T. and Clemente, L.H. (2015) Brazilian Savanna Re-Establishment in a Monoculture Forest: Diversity and Environmental Relations of Native Regenerating Understory in Pinus caribaea Morelet. Stands. Journal of Forestry Research, 26, 571-579. http://dx.doi.org/10.1007/s11676-015-0050-z

[33] Felfili, J.M., Carvalho, F.A. and Haidar, R.F. (2005) Manual para monitoramento de parcelas permanentes nos biomas Cerrado e Pantanal. Universidade de Brasília, Brasília.

[34] Chase, M.W. and Reveal, J.L. (2009) A Phylogenetic Classification of the Land Plants to Accompany APG III. Botan- 
ical Journal of the Linnean Society, 161, 122-127. http://dx.doi.org/10.1111/j.1095-8339.2009.01002.x

[35] Canfield, R. (1941) Application of Line Interception Method in Sampling Range Vegetation. Journal of Forestry, 39, 388-394.

[36] Bullock, J. (1996) Plants. In: Sutherland, W.J., Ed., Ecological Census Techniques—A Handbook, Cambridge University Press, Cambridge, 111-138.

[37] Hair, J.F., Black, W.C., Babin, B.J. and Anderson, R.E. (2005) Análise Multivariada de dados. 5th Edition, Bookman, Porto Alegre.

[38] R Development Core Team (2015) R: A Language and Environment for Statistical Computing. http://www.r-project.org/

[39] Brandão, M. (2000) Cerrado. In: Mendonça, M.P. and Lins, L.V., Eds., Lista Vermelha das Espécies Ameaçadas de Extinção da Flora de Minas Gerais, Fundação Biodiversitas, Belo Horizonte, 55-63.

[40] Mack, R.N., Simberloff, D., Lonsdale, M.W., Evans, H., Clout, M. and Bazzaz, F.A. (2000) Biotic Invasions: Causes, Epidemiology, Global Consequences, and Control. Ecological Applications, 10, 689-710. http://dx.doi.org/10.1890/1051-0761(2000)010[0689:BICEGC]2.0.CO;2

[41] Bechara, F.C., Reis, A., Bourscheid, K., Vieira, N.K. and Trentin, B.E. (2013) Reproductive Biology and Early Establishment of Pinus elliottii var. elliottii in Brazilian Sandy Coastal Plain Vegetation: Implications for Biological Invasion. Scientia Agricola, 70, 88-92. http://dx.doi.org/10.1590/S0103-90162013000200005

[42] Whitmore, T.C. (1990) An Introduction to Tropical Rain Forests. Clarendon Press, Oxford. 